International Journal of Advanced Chemistry, 8(2)(2020) 217-224
International Journal of Advanced Chemistry
SPC
Website: www.sciencepubco.com/index.php/IJAC
Research paper

\title{
Optimization of groundnut shell fast pyrolysis for the production and characterization of bio-oil using fabricated fixed bed reactor
}

\author{
Ige Ayodeji Rapheal ${ }^{1 *}$, Elinge Cosmos Moki ${ }^{1}$, Aliyu Mohammad ${ }^{1}$, Gwani \\ Muhammed $^{2}$, Lawal Gusau Hassan ${ }^{3}$ \\ ${ }^{l}$ Department of Pure and Applied Chemistry, Kebbi State University of Science and Technology, Aliero, Kebbi State, Nigeria \\ ${ }^{2}$ Department of Physics, Kebbi State University of Science and Technology, Aliero, Kebbi State, Nigeria \\ ${ }^{3}$ Department of Pure and Applied Chemistry, Usmanu Danfodiyo University, Sokoto, Nigeria \\ *Corresponding author E-mail:igeayodeji2@gmail.com
}

\begin{abstract}
Renewable plant materials are regarded as one of the most affirmative option for the production of fuels and chemicals. With the concept of pyrolysis process, there is every possibility to produce alternative sources of energy and fuels from renewable biomass. The study depicts the production, optimization and characterization of bio-oil from pyrolyzed groundnut shell using fabricated reactor. The pyrolysis process was produced with bio-oil response, bio-char response and non condensable gases response as products. The effect of pyrolysis variables were observed by the production of the bio-oil as the response. Sixty runs of pyrolysis experiments were suggested by box Benkhen design indicated optimum pyrolysis condition at particle size of $1.15 \mathrm{~mm}$ mesh, reaction time of 83 mins and temperature of $650 \mathrm{oC}$. The maximum bio-oil yield was obtained with $33.91 \%$ at optimum condition. The bio-oil samples had better performance which met the specifications for the measured properties and compares well with the ASTM standard. Therefore, using groundnut shell for biooil production via pyrolysis process can serve as an approach of providing a sustainable alternative source of fuel and friendly environment.
\end{abstract}

Keywords: Pyrolysis; Variables; Temperature; Particle Size; Reaction Time.

\section{Introduction}

Rapid concern in seeking for alternative source of energy which is renewable energy has influence in the development of solar, wind biomass conversion devices etc., for efficacious energy creation (Dermibas, 2006). The increase in energy need and rising in environmental issues, the recent and clean energy sources are being investigated to avoid feasible damages from global warming and climate change. Biomass is widely spread globally, and it is often available at low cost. It could therefore be suitable as the world's relevant renewable energy resource (Daya et al., 2014).

Biomass is an organic matter that is obtained from plants, cereals, algae, animal wastes. It is bountifully obtainable due to its availability and also that carbon produced is harmless. It is made up of three main parts which are cellulose, hemicelluloses and lignin. Many processes have been sequentially produced to change agricultural and forestry wastes into a beneficial use through thermo-chemical conversion (Dermibas, 2009).

In terms of converting inexpensive, indigenous and bountiful agricultural wastes especially lignocellulosic biomass into a beneficial use, a process which is known as pyrolysis as shown an affirmation thermo-chemical conversion due to empirical evidences. Pyrolysis is a process of heating biomass material in a close vessel without infiltration of oxygen while three major products are gotten which is biooil, bio-char and non condensable gases (Mohan et al., 2006; Lu et al., 2010).

Groundnuts (Arachis hypogea L) were brought into existence by Latin America. The Portuguese from Brazil recommended groundnut production into the African continent in the $16^{\text {th }}$ century (Adinya et al., 2010). Many studies have affirmed that groundnut seed has nutritional sources for health improvement (Food Agricultural Organization, 2006). The research aim is to examine the optimization and characterization of bio-oil pyrolyzed from groundnut shell. The main objectives of this study are to determine the yield of the bio-oil at most favourable condition, physic-chemical properties of the sample and the fuel tests of the sample.

\section{Meterials and methods}

\subsection{Biomass samples preparation}


The groundnut shells were collected from Aliero, Aliero Local Government Area, Kebbi State, Nigeria. The groundnut shells were pulverized and rinsed with tap water to remove impurities and were dried in the oven at $105{ }^{\circ} \mathrm{C}$ for $24 \mathrm{hr}$. The dried pulverized biomass was stored in air-tight containers until further use (Kasim et al., 2018).

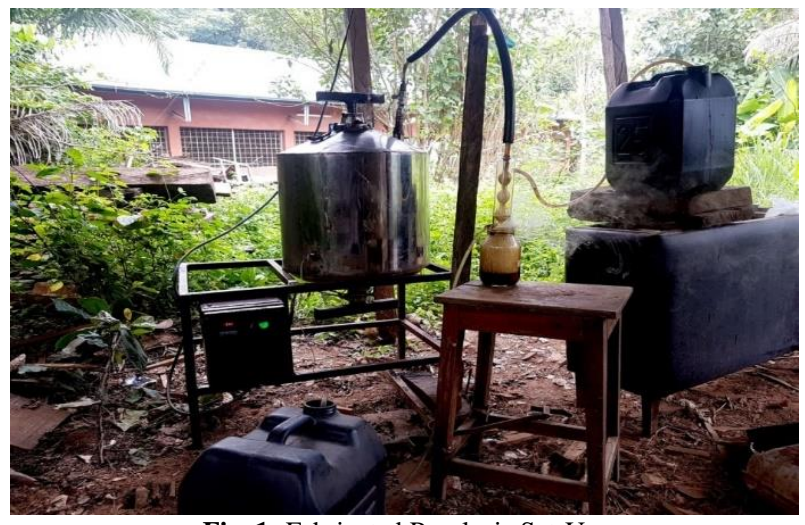

Fig. 1: Fabricated Pyrolysis Set-Up.

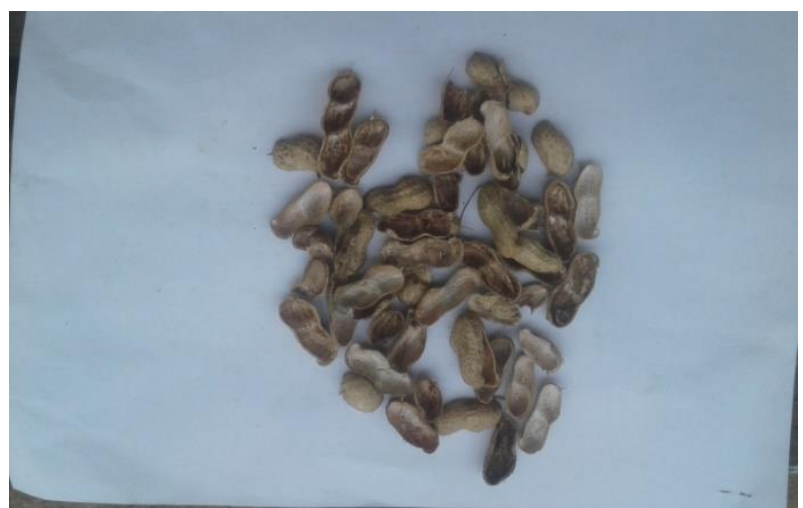

Fig. 2: Groundnut Shells.

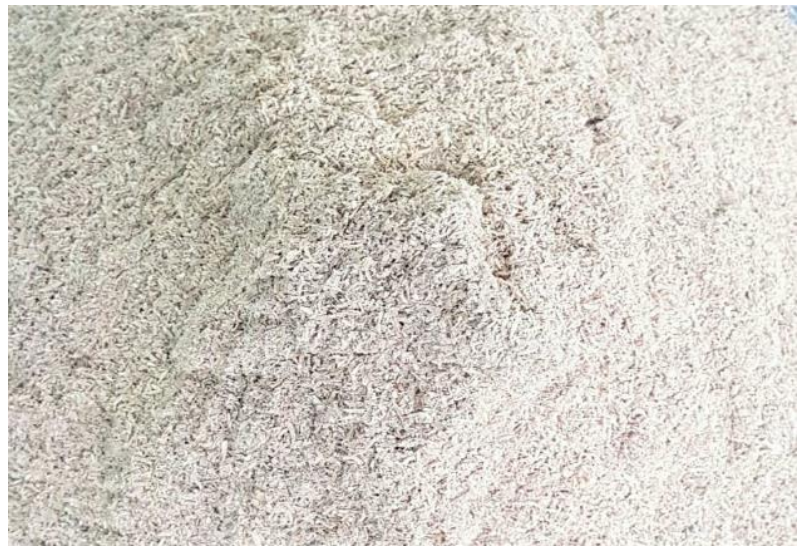

Fig. 3: Groundnut Shells Sample.

\subsection{Methods}

\subsubsection{Sample preparation}

Fabricated Pyrolytic chamber was use (Fig. 1) for the extraction of groundnut shells. The reactor was made from stainless steel plate to prevent rusting, also connected to a glassware condenser for condensation process with reactor fixed stock capacity of $1 \mathrm{Kg}$ and electrical heater capacity $1 \mathrm{Kw} .1 \mathrm{Kg}$ of the groundnut shells were filled into the reactor which was connected to a condenser. The evolving gases were distilled in the condenser to form bio-oil and were collected inside a conical flask.

The fabricated fixed bed reactor is without the solid catalyst particles being loaded. This is to determine the efficiency of the reactor on the yield and quality of bio-oil produced without using catalyst and also to save cost.

The formula below was adopted for yield calculation by (Ogunsanwo and Adegoke, 2011).

Bio-oil Yield (\%) $=\frac{\text { weight. of liquid produced }}{\text { weight of incipient pyrolysis material }} \times 100$

Solid Yield $(\%)=\frac{\text { weight. of solid produced }}{\text { weight of incipient pyrolysis material }} \times 100$

Non Condensable Gases $=100-($ Solid Yield + Liquid Yield $)$ 


\subsubsection{Experimental design}

Response surface methodology (Box-Behnken) was used for the optimization experiments using Minitab 17 statistical software at a D 0.05(95\% confidence level) according to (Ogala and Ige, 2019). Self-standing parameters such as temperature, particle size and time were chosen for the inquiry. The runs were wholly randomized to procure at sum of 60 runs to determine the efficiency and sustainability of the optimum parameters.

Table 1: Optimization Processes Variables

\begin{tabular}{lll}
\hline Factor & Lower Level & Upper Level \\
\hline Particle Size $(\mathrm{mm})$ & 1.00 & 4.00 \\
Temperature $\left({ }^{\circ} \mathrm{C}\right)$ & 500 & 650 \\
Time $(\min )$ & 30 & 120 \\
\hline
\end{tabular}

\subsubsection{Determination of physico-chemical properties}

The physic-chemical properties of the maximum bio-oil yield produced using response surface methodology were evaluated.

\subsubsection{1. pH determination}

To evaluate the corrosive property of the bio-oil products, the $\mathrm{pH}$ of the bio-oil was measured using a pH meter from Eutech Instruments. The sample size of bio-oil was 1-2 ml. The recorded value is the final result, expressed as a $\mathrm{pH}$ of bio-oil.

\subsubsection{Determination of moisture content ASTM D 1744}

The moisture content of the bio-oil was determined using Karl Fischer Titrator, type 784 KFP Titrino, Metrohm was according to American Society for Testing and Materials (2007). The bio-oil was titrated with standard Karl Fischer reagent to an electrometric end point.

\subsubsection{Ash content}

The ash content of the bio-oil sample was determined using Kyari, (2008) procedure which is calculated using formula 4.

Ash Content $=\frac{\text { Ma-Mo }}{\mathrm{Ms}} \times 100$

Where, Ma= Mass of crucible plus ash, Mo= Mass of empty crucible, Ms= Mass of sample

\subsubsection{Density determination of bio-oil from groundnut shell ASTM D (American standard test method) 4052}

The density of a material is defined as mass per unit volume of sample and this was determined according to ASTM (1998) using digital density analyzer. Firstly, the density meter was calibrated by water at $25^{\circ} \mathrm{C}$ before measurement in order to minimize the errors. Then, 1 $\mathrm{ml}$ of bio-oil was injected into the density meter at $25^{\circ} \mathrm{C}$ and repeated three times. The average value is the final result, expressed as density in $\mathrm{g} / \mathrm{cm}^{3}$.

\subsubsection{Determination of acid value}

The acid value of the groundnut shell bio-oil sample was determined according to Kyari, (2008) using equation (5).

$\mathrm{A} \cdot \mathrm{V}=\frac{56.1 \times \mathrm{V} \times \mathrm{M}}{\mathrm{m}}$

Where $\mathrm{V}=$ volume of $\mathrm{KOH}$ used; $\mathrm{M}=$ molarity of $\mathrm{KOH}$ and $\mathrm{m}=$ mass of sample.

\subsubsection{Determination of fuel properties}

The fuel properties of the maximum bio-oil yield produced using response surface methodology were determined.

\subsubsection{Gross calorific value of bio-oil from groundnut shell (ASTM D-396)}

The gross calorific value is a measure of the quantity of heat released in total combustion and therefore, measures the energy content of a fuel. The calorific value of bio oil was determined by burning a weighed sample in an oxygen-bomb calorimeter, Leco AC-350 under controlled conditions based on ASTM, (2016) procedure. The test procedure consists of adding the weighed of bio oil samples to the cup (approximately $0.5-1.0 \mathrm{ml}$ ), installing a fuse, and charging the bomb with oxygen to approximately 200 psi. The heat of combustion was computed from temperature observations before, during, and after combustion, with proper allowance for thermo-chemical and heat transfer corrections. It is the most important fuel property of any liquid fuel.

\subsubsection{Kinematic viscosity at 40o C (ASTM D 445-06)}

A viscometer was placed into a water bath with an adjustable temperature and remained for 30 minutes. The bio-oil was coalesce to the viscometer and was left in the water bath to reach the thermometer. Bio-oil was permitted to flow excellently and the time demanded for the meniscus to pass from the first mark several times to ascertain an average value was the multiplied with the viscometer calibration according to ASTM, (2006). 


\subsubsection{Flash point (ASTM D 93-08)}

Flash point is a measure of the liquid temperature necessary for the vapours above a pool of the fuel to ignite by passing a flame through the vapours. This is also a measure of the volatility of the oil, as well as its ease of ignition. The higher this number, the safer the oil is to handle because the risk of accidental vapor ignition is reduced. The flash point was determined using ASTM, (2008) by heating a sample of the fuel in a stirred container and passing a flame over the surface of the liquid. At temperature at or above the flash point, the vapour ignited and an easily detectable flash was observed. It is an index of fire risk during storage under ambient conditions. A sample is deemed to have flashed when a large flame appears and instantaneously propagates itself over the entire surface of the test specimen.

\subsubsection{Pour point (ASTM D 97-11)}

The pour point is the lowest temperature at which the liquid is observed to flow under prescribed conditions. This parameter is an indication of the minimum temperature at which the oil can be pumped without heating the storage tank. The bio-oil sample was restrained in the freezer at about $500{ }^{\circ} \mathrm{C}$ them placed in a heating mantle to melt. The temperature at which the bio-oil begins to pour was determined as pour point according to ASTM, (2011).

\section{Results}

Table 2:Experimental Design Matrix and Results of Groundnut Shell (Pyrolysis Yield) from the Experimental Runs

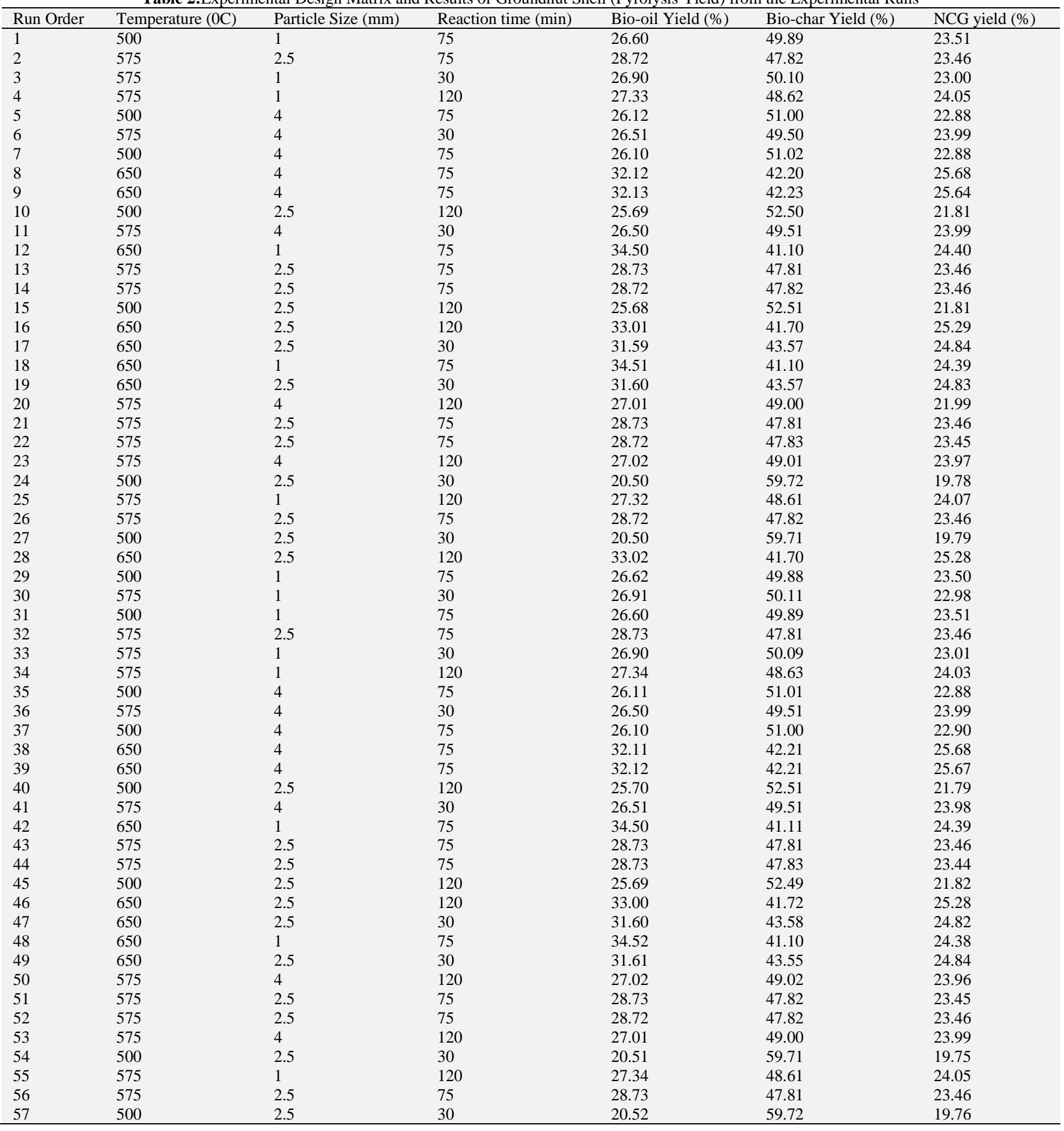




\begin{tabular}{lllllll}
\hline 58 & 650 & 2.5 & 120 & 33.02 & 41.72 & 25.26 \\
59 & 500 & 1 & 75 & 26.60 & 49.88 & 23.52 \\
60 & 575 & 1 & 30 & 26.91 & 50.10 & 22.99 \\
\hline
\end{tabular}

Table 3:Result of Variance for Groundnut Shell Bio-Oil Yield (\%)

\begin{tabular}{|c|c|c|c|c|c|}
\hline Source & $\mathrm{DF}$ & Adj SS & Adj MS & F-Value & P-Value \\
\hline Model & 9 & 625.518 & 69.502 & 64.33 & 0.000 \\
\hline Linear & 3 & 566.246 & 188.749 & 174.71 & 0.000 \\
\hline Temperature $(\mathrm{T})$ & 1 & 523.423 & 523.423 & 484.51 & 0.000 \\
\hline Time $(\mathrm{t})$ & 1 & 40.613 & 40.613 & 37.59 & 0.000 \\
\hline Square & 3 & 54.096 & 18.032 & 16.69 & 0.000 \\
\hline Temperature*Temperature $\left(\mathrm{T}^{2}\right)$ & 1 & 12.892 & 12.892 & 11.93 & 0.001 \\
\hline Particle size*Particle size $\left(\mathrm{P}^{2}\right)$ & 1 & 0.591 & 0.591 & 0.55 & 0.463 \\
\hline Time*Time $\left(\mathrm{t}^{2}\right)$ & 1 & 37.167 & 37.167 & 34.40 & 0.000 \\
\hline 2-way interaction & 3 & 5.177 & 1.726 & 1.60 & 0.202 \\
\hline Temperature*Particle size $(\mathrm{T} * \mathrm{P})$ & 1 & 0.152 & 0.152 & 0.14 & 0.709 \\
\hline Temperature*Time $(\mathrm{T} * \mathrm{t})$ & 1 & 5.018 & 5.018 & 4.64 & 0.036 \\
\hline Particle size ${ }^{*}$ Temperature $\left(\mathrm{P}^{*} \mathrm{~T}\right)$ & 1 & 0.007 & 0.007 & 0.01 & 0.937 \\
\hline Error & 10 & 0.002 & 0.002 & & \\
\hline Total & 20 & 0.023 & 0.023 & & \\
\hline
\end{tabular}

$\mathrm{DF}=$ degree of freedom, Adj SS = adjusted sum of squares, Adj MS = adjusted mean squares,

$\mathrm{F}=\mathrm{F}$-statistics, $\mathrm{P}=\mathrm{p}$-value, and $\mathrm{S}=$ statistically significant.

Regression Equation in Uncoded Units

Bio-oil Yield $(\%)=37.9-0.1225 \mathrm{~T}+0.74 \mathrm{P}+0.2372 \mathrm{t}+0.000166 \mathrm{~T}^{2}-0.089 \mathrm{P}^{2}-0.000783 \mathrm{t}^{2}-0.00087 \mathrm{~T} * \mathrm{P}-0.000166 \mathrm{~T} * \mathrm{t}+0.00031 \mathrm{P} * \mathrm{t}$

Analysis of variance

Model: These tests whether the terms in the model have any effect on the response; for regression model to be significant $(\mathrm{P}<0.05)$. The $\mathrm{P}$-value observed was $(\mathrm{P}=0.000)$ which is a clear indication that, at least one of the terms in the model has an impact on the mean response. Model is further broken into different orders of terms in the model namely; linear, square, and interaction effect.

Linear effect; for temperature $(\mathrm{P}=0.000)$ is less than 0.05 . Therefore, temperature has linear effect on the model whereas $\mathrm{P}$-value for particle size $(\mathrm{P}=0.159)$ is greater than $(\mathrm{P}<0.05)$ and time $(\mathrm{P}=0.000)$ is less than $(\mathrm{P}<0.05)$ which shows that time has linear effect on the model and particle size has no linear effect on the model.

Squared effects: Squared terms are used to evaluate whether or not there is curvature in the response surface. The p-value of 0.000 for the squared effects is less than 0.05 . Therefore, there is significant evidence of a quadratic effect. The individual $\mathrm{p}$-values for temp*temp, particle size* particle size and time*time and are $0.001,0.463,0.000$.

Interaction effects: The p-value of 0.202 is more than 0.05 ; therefore, there is no significant evidence of interaction effects. The temperature by time interaction is less than 0.05 . Therefore, there is a significant interaction effect. That is, the effect of temperature on reaction yield depends on the time.

\begin{tabular}{llll}
\hline $\mathrm{S}$ & $\mathrm{R}^{2}$ & $\mathrm{R}^{2}(\operatorname{adj})$ & $\mathrm{R}^{2}(\mathrm{pred})$ \\
\hline 1.03939 & $92.05 \%$ & $90.62 \%$ & $87.96 \%$ \\
\hline
\end{tabular}

For the pyrolysis data, $92.05 \%$ of the variation in yield is explained by model, the predicted $\mathrm{R}$ is $87.96 \%$, and the adjusted $\mathrm{R}$ is 90.62 $\%$. The lower $\mathrm{R}^{2}$ may indicate that the model is overfit.

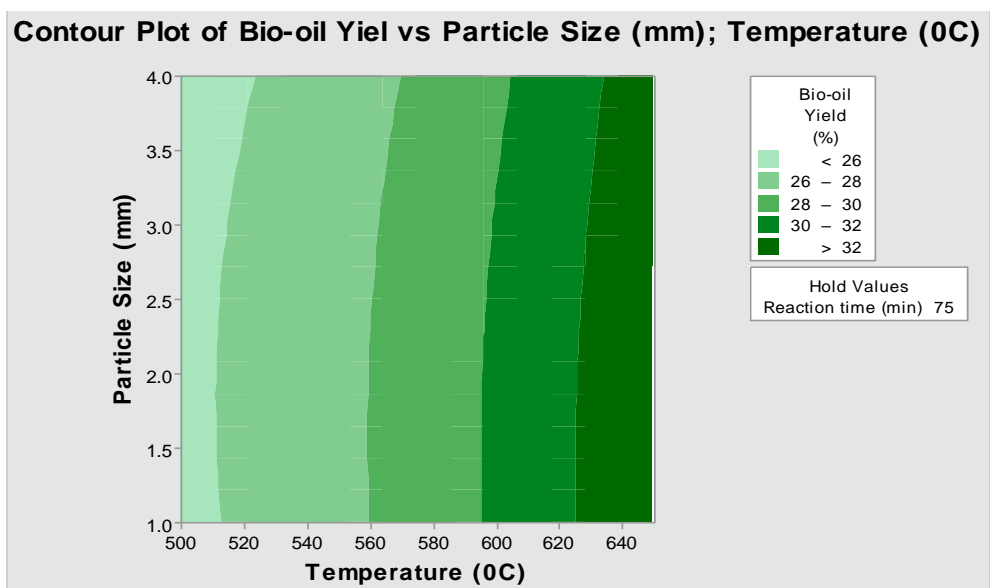

Fig. 4:Contour Plot Showing the Combined Effect of Bio-Oil Yield on Particle Size and Temperature when Time Held Constant for Groundnut Shell. 


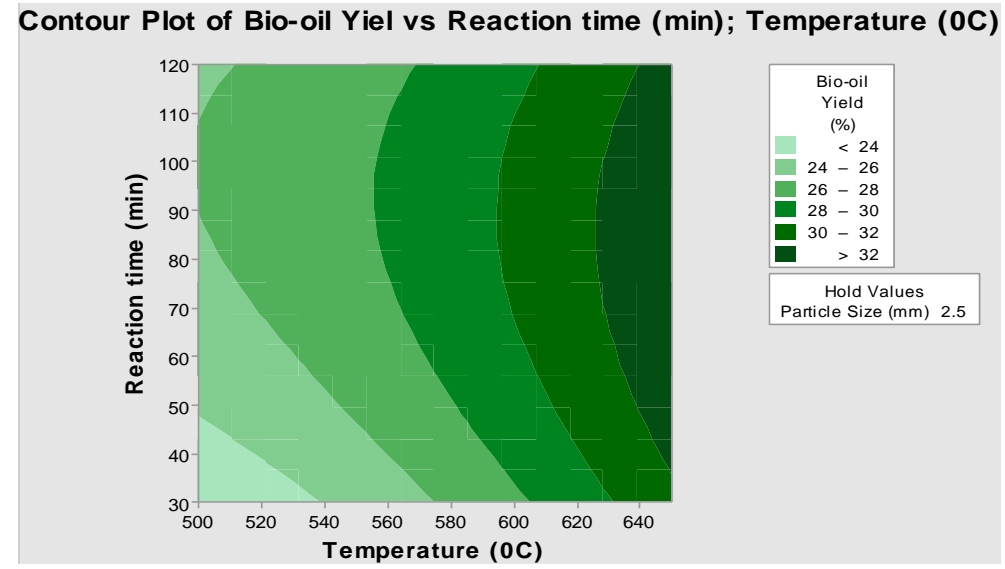

Fig. 3:Contour Plot of Bio-Oil Yield on Time Versus Temperature when Particle Size Remained Constant for Groundnut Shell.

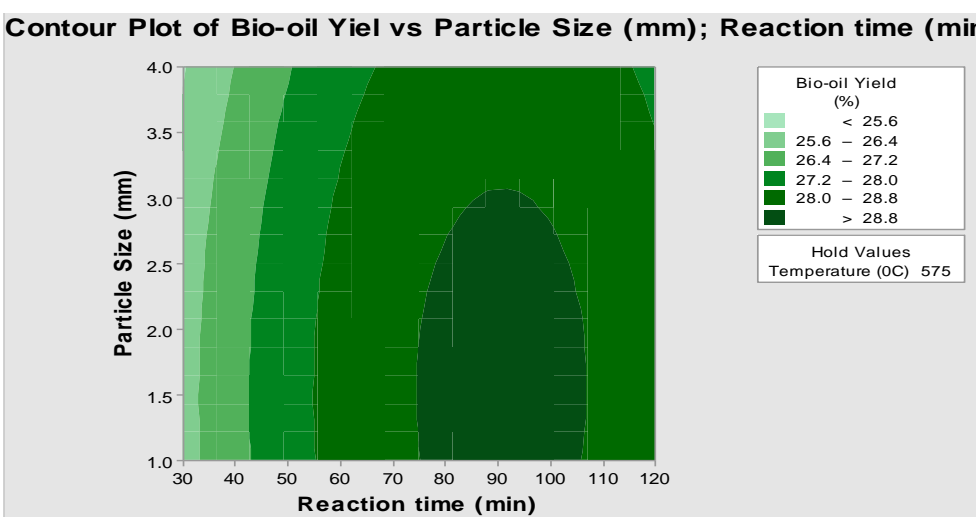

Fig. 5:Contour Plot of Bio-Oil Yield on Particle Size and Particle Size when Temperature Held Constant for Groundnut Shell.

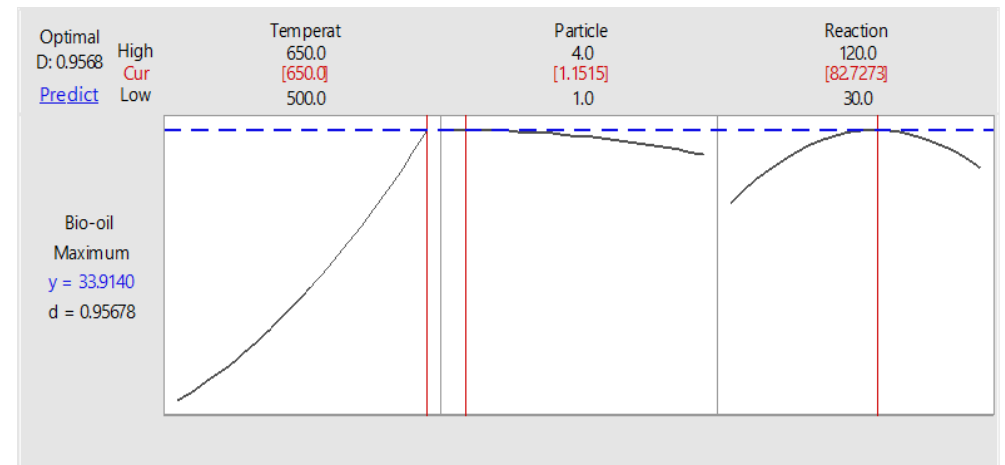

Fig. 6: Optimization Plot for Groundnut Shell.

Table 4:Physicochemical Properties of Bio-Oil

\begin{tabular}{lcccc}
\hline Bio-oil Samples & Ash Content $(\%)$ & Density $\left(\mathrm{g} / \mathrm{cm}^{3}\right)$ & $\mathrm{pH}$ & Moisture content $(\%)$ \\
\hline Groundnut Shell & $0.03 \pm 0.61$ & $1.07 \pm 0.02$ & $2.58 \pm 0.10$ & $20.05 \pm 0.10$
\end{tabular}

Values are mean standard deviation of triplicate results.

Table 5:Fuel Properties of Bio-Oil

\begin{tabular}{lllll}
\hline Bio-oil Samples & Kinematic Viscosity $\left(\operatorname{Cot}\left(\mathrm{mm}^{2} / \mathrm{s}\right)\right)$ & Flash Point $\left({ }^{\circ} \mathrm{C}\right)$ & Pour Point $\left({ }^{\circ} \mathrm{C}\right)$ & $\mathrm{Calorific}$ Value $(\mathrm{Kcal} / \mathrm{Kg})$ \\
\hline Groundnut Shell & $22.85 \pm 0.50$ & $111.00 \pm 0.00$ & $-10.00 \pm 0.00$ & $3800 \pm 0.20$
\end{tabular}

Values are mean standard deviation of triplicate results.

\section{Discussion}

Bio-oil yield optimization was investigated using Minitab 17 statiscal software. Fig. 4 to fig. 6 reveals three optimal variables procured from the optimization.

Bio-oil yield of $33.91 \%$ for groundnut shell was achieved from justifiable experiments conducted at the levels of the process variables suggested. Although one-sample t-test reveals that the empirical yield is significantly less than the model prediction, the two are quite close with a difference of less than $1 \%$. This further indicates that the empirical model obtained from the response surface design is highly reliable and a very good presentation of the process. It is noteworthy that higher yields can be obtained at the various variables optimized.

Particle size and reaction time has an influence on the bio-oil yield. When reaction time was under 30 minutes, bio-oil yield was $24.80 \%$ with respect to the particle size at $4 \mathrm{~mm}$ mesh for groundnut shell while when reaction time was under 30 minutes, the bio-oil yield was $29 . .92 \%$ with respect to the particle size at $4 \mathrm{~mm}$ mesh for groundnut shell. Maximum yields of bio-oil (>28.8\% for groundnut shell) was obtained when the pyrolysis was conducted for 70 to 110 minutes. 
The effect of interaction between particle size and temperature on bio-oil yield showed that bio-oil yields of over $32 \%$ for groundnut shell can be obtained when the particle size was $1 \mathrm{~mm}$ at $650{ }^{\circ} \mathrm{C}$ for groundnut shell.

The $\mathrm{pH}$ of bio-oil obtained from groundnut shell in compare well with the $\mathrm{pH}$ of corn stover (3.0), big bluestem (3.4) and Praire cord grass (3.6) respectively as reported by Muthukumarappan, (2011). The recorded density value for groundnut shell is $1.07 \mathrm{gcm}^{-3}$ as shown in Table 4. Abdullah and Gerhauser (2008) revealed that bio-oil has a density of $1.2 \mathrm{~g} / \mathrm{cm}$ which makes it a highly dense liquid which is in agreement with the value of density obtained for the sample.

The bio-oil sample has the moisture content of $20.05 \%$. The result obtained is in line with the result of Kang et al., (2013), he revealed that moisture content of the biomass studied ranged from 27-38\%. It is also compare well to the palm shell bio-oil as reported by Oasmaa et al., (2009); Abnisa et al., (2013a).

Present of ash in the bio-oil can resulted to rust and corrosion of the engine. As reported by Peacocke, (1994) when the ash content of bio-oil is higher than $0.1 \%$, the problems become more trifling. In line with that, the results obtained are lower than $0.10 \%$. The results obtained are also consistent with past reported results of Pattiya et al., (2007).

Corrosion and rust always very intense at high temperature due to high acidity level which tends to more research and developing devices to curb corrosion in the bio-oil produced. The acid value of the bio-oil sample for groundnut shell is $13.20 \mathrm{mg} \mathrm{KOH} / \mathrm{g}$. The increase in time of storage of biomass leads to higher acid value.

Hence, the corrosivity of the samples is comparable to that of the result reported by Ikura et al., (2003) due to organic acids present.

Kinematic viscosity was observed at $40^{\circ} \mathrm{C}$ for groundnut shell sample. The results are higher than the viscosity of date seed waste (6.63 cSt) reported by Mohammad et al., (2009). Viscosity depicts the movement property of the bio-oil.

The flash point obtained is compare well with the result reported by Khor et al., (2009); Chiaramonti., et al., (2003a) ranged from $65^{\circ} \mathrm{C}$ to $99^{\circ} \mathrm{C}$. It determines the volatility of the bio-oil and its ability to ignite.

Pour point is a criterion used to determine the performance of bio-oil at lower temperature, to know whether it may/may not have any effect in lower temperature. The pour point value of $-10{ }^{\circ} \mathrm{C}$ was recorded. The result of this work (-10) is in agreement or falls with the ASTM range of $\left(-15-\left(-10^{\circ} \mathrm{C}\right)\right)$ and compare well with $-14{ }^{\circ} \mathrm{C}$ and $-17{ }^{\circ} \mathrm{C}$ for palm shell and cassava pulp respectively reported by Piyarat and chiyot, (2007).

The result of this work recorded $3800 \mathrm{Kcal} / \mathrm{Kg}$ for groundnut shell bio-oil sample which falls below the ASTM specification $(43 \mathrm{MJ} / \mathrm{Kg})$ and the result is lower when compared to the works of coconut shell seed oil with $21.4 \mathrm{MJ} / \mathrm{Kg}$ and date seed oil with $28.63 \mathrm{MJ} / \mathrm{Kg}(\mathrm{Mo}-$ hammad, et al., 2009).

\section{Conclusion}

The best variables condition was achieved for groundnut shell in a pyrolysis process with a fabricated reactor using surface response methodology. The optimum condition was observed at temperature of $650^{\circ} \mathrm{C}$, particle size of $1.15 \mathrm{~mm}$ mesh and reaction time of 83 minutes at bio-oil yield of $33.91 \%$. The bio-oil sample had better performance which met the specifications for the measured properties. The optimum conditions obtained would be appropriate for the production of bio-oil using the fabricated fixed bed reactor. Therefore, fast pyrolysis of groundnut shell for bio-oil production would be a suitable approach of providing a sustainable alternative source of fuel and friendly environment.

\section{References}

[1] Abdullah, N. \& Gerhauser, H. (2008). Bio-oil Derived from Empty Fruit Bunches. Fuel 87(12): 26062613.https://doi.org/10.1016/j.fuel.2008.02.011.

[2] Adinya, I.B., Enun, E.E and Ijoma, J.U., 2010. Exploring Profitability Potential in Groundnut (Arachis hypogaea) Production through Agroforestry Practices: A case study in Nigeria. The Journal of Animal and Plant Sciences, 20, (2):123-131.

[3] Abnisa, F., Arami-Niya, A., Wan, D. \&Sahu, J.N. 2013a. Characterization of Bio-oil and Biochar from Pyolysis of Palm Oil Wastes. BioEnergy Research 6(2): 830-840.https://doi.org/10.1007/s12155-013-9313-8.

[4] ASTM D 396 (2016). Specifications of biofuels.

[5] ASTM D97-11 (2011). Standard Test Method for pour point of petroleum products. ASTM Inter. west Conshohocken, PA.

[6] ASTM D93-08 (2008). Standard Test Method for flash point by Pensky-Martens closed cup tester. ASTM Inter. west Conshohocken, PA.

[7] ASTM D 482-07 (2007). Standard Test Method for Ash from Petroleum Products. American Society for Testing and Materials.

[8] ASTM D445-06 (2006). Standard Test Method for kinematic viscoscity of transparent and opaque liquids. ASTM Inter. west Conshohocken, PA.

[9] ASTM D 4052. (1988): Standard test method for density and relative density of liquids by digital density meter. Easton, MD: American Society for Testing and Materials.

[10] Chiaramonti, D., Bonini, A., Fratini, E. (2003a): Development of emulsions from biomass pyrolysis liquid and diesel and their use in engines Part 1: emulsion production. Biomass \& Bioenergy, Vol.25, No.1, pp. 85-99, ISSN 0961-9534.https://doi.org/10.1016/S0961-9534(02)00183-6.

[11] Demirbas, A. (2006): Global renewable energy resources. Energy Sources Part A Recovery Utilisation in. Environment. Eff28, 779792.https://doi.org/10.1080/00908310600718742.

[12] Dermibas, A. (2009). Progress and recent trends in Biodiesel fuels. Energy conversion and management, 50, 1434.https://doi.org/10.1016/j.enconman.2008.09.001.

[13] Daya R. N., Prabir B and Bishnu A., (2014). A Comprehensive Review on Biomass Torrefaction. International Journal of Renewable Energy \&

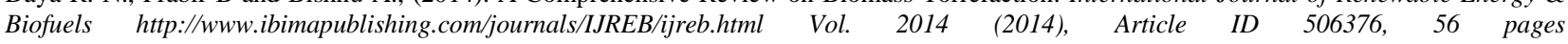
https://doi.org/10.5171/2014.506376.

[14] FAO. Production yearbook, Rome, Italy.2006;60.

[15] Ikura M., Stanciulescu M., Hogan, E., (2003): Emulsification of pyrolysis derived bio-oil in Biodiesel fuel. Biomass Bioenergy, 24, $221-232$. https://doi.org/10.1016/S0961-9534(02)00131-9.

[16] Kang, B., Lee, K.H., Park, H.J. (2013). Fast pyrolysis of radiate pine in a bench scale plant with a fluidized bed: Influence of a char separation system and reaction conditions on the production of bio-oil. J. Anal. Appl. Pyrolysis 2006, 76,32-37.https://doi.org/10.1016/j.jaap.2005.06.012.

[17] Kasim N.N, Mohamed A.R, Ishak M.A.M, Ahmad R, Nawawi W.I, Ismail K, Salleh N.H.M (2018). "Optimization of pyrolysis process parameters of torrefied demineralized palm empty fruit bunch (TDEFB) by response surface methodology", AIP Publishing.https://doi.org/10.1063/1.5054202.

[18] Khor K. H., Lim K. O., Zainal, Z. A., (2009). Characterization of bio-oil: a by-product from slow pyrolysis of oil palm empty fruit bunches, Am. $J$. of Applied Sci. 6 1647-1652.https://doi.org/10.3844/ajassp.2009.1647.1652.

[19] Kyari, M.Z. (2008). Extraction and Characterization of Seed Oils. International Agrophysics, 22, 139-142.

[20] Mohamad A. S., Chow M. C., and Nor K. A. B., (2009). Bio-oils from Pyrolysis of Oil Palm Empty Bunches," American Journal of AppliedSciences, vol. 6, no. 5, pp. 869-875.https://doi.org/10.3844/ajas.2009.869.875. 
[21] Mohan, D., Pittman, C. U., Steele, P. H., (2006). Pyrolysis of wood/biomass for bio-oil: A critical review. Energy \& Fuels, 20, 848889.https://doi.org/10.1021/ef0502397.

[22] Muthukumarappan K, Sivasastri, A., Karunanithy, C. (2011). Characteriztion of Biochar and Bio-oil Produced from Different Feedstocks. Journal of Agricultural Machinery Science 7(4), 351-354.

[23] Lu, Q., Zhang, Z. F., Dong, C. Q., Zhu, X. F (2010) Catalytic upgrading of biomass fast pyrolysis vapors with nano metal oxides: An analytical PyGC/MS study. Energies 3, 1805-1820.https://doi.org/10.3390/en3111805.

[24] Oasmaa A, Elliott, D. C., and Muller, S. (2009). Quality Control in Fast Pyrolysis Bio-oil Production and Use. Environmental Progress and Sustainable Energy 28, 404-409. https://doi.org/10.1002/ep.10382.

[25] Ogala H., Ige A. R (2019). Application of Response Design for the Optimization of Biodiesel Production from Desert Date (Balanitea egyptiaca) oil. AASCIT Journal of Energy. Vol.6, No.1, 2019, p.1-7.

[26] Ogunsanwo, O. Y., and Adegoke, I. A., (2011): Thermo-Chemical Characterization of Bio-Oil Produced from Sawdust of Three Wood Species in Nigeria Journal of Environmental Extension, Vol. 10 (1)

[27] Pattiya A., James O.T., Bridgwater A. V., (2007). Fast Pyrolysis of Agricultural Residues from Cassava Plantation for Bio-oil Production. Asian Journal on Energy and Environment, Issn 1513-4121, 08(02), 496-502.

[28] Piyarat, W. and Chiyot, T (2007). Fuel Properties and ChemicalCompositions of Bio-oils from Biomass Pyrolysis. Journal of Society of Automatic Engineers of Japan; JSAE 2007087, SAE 2007-01-2024.

[29] Peacocke, G. V., P. A. Russel, J. D. Jenkins, A. V. Bridgwater, (1994), Physical Properties of Flash Pyrolysis Liquid. Biomass and Bioenergy, 7 : 169-178.https://doi.org/10.1016/0961-9534(94)00056-Y 